Article

\title{
Why COVID-19 Will Not Change the Global Art Market
}

\author{
Feliks Tuszko (D)
}

check for updates

Citation: Tuszko, Feliks. 2021. Why COVID-19 Will Not Change the Global Art Market. Arts 10: 50. https://doi.org/10.3390/arts10030050

Academic Editor: Elena Sidorova

Received: 28 May 2021

Accepted: 29 June 2021

Published: 27 July 2021

Publisher's Note: MDPI stays neutral with regard to jurisdictional claims in published maps and institutional affiliations.

Copyright: (C) 2021 by the author. Licensee MDPI, Basel, Switzerland. This article is an open access article distributed under the terms and conditions of the Creative Commons Attribution (CC BY) license (https:/ / creativecommons.org/licenses/by/ $4.0 /)$.
Department of Sociology, University of Warsaw, 00-927 Warsaw, Poland; f.tuszko@uw.edu.pl

\begin{abstract}
This article investigates the valuation of artworks during the COVID-19 pandemic. It examines how art market participants employ fictional expectations of the future to stabilize valuations during uncertain times. A total of 86 forecasts originating from both the center and periphery of the global art market were analyzed. Taking a meta-analytic approach, focus was placed on what each analysis predicts, how it constructs the future it purports to know, and how the expected value of artworks and methods for their purchase are justified. This uncovered the paradoxical reality of art market forecasts-their authors are convinced that the power of crisis could reformulate the art market, but their conclusions do not assume the possibility of real change. Further, the argument is made that speculation about the future is at the core of today's art economy. Therefore, in a crisis, market participants conservatively orient themselves toward artworks that already have established value.
\end{abstract}

Keywords: art market; COVID-19; forecasts; valuation studies; sociology of art; artworks; visual arts

\section{Introduction}

Let us review the press and reports titled "The Impact of COVID-19 on the Art Market", "Art will survive the hard times of the plague", "On the future of the art market and art fairs post-coronavirus", and "How are galleries and institutions adapting to the art world's 'new normal'?". Similarly, the main question posed in this Special Issue of the Arts journal is "How has COVID-19 affected the global art market?". Searching for signs of the impact of the pandemic on the art market and trying to predict its future have together become a central problem for analysts. Inherent within these and similar countless statements and queries is a firm conviction that the pandemic is a crisis, an extraordinary situation. Depending on the context, this crisis is treated as a moment of truth, a moment of trial, or a moment of revaluation (Koselleck and Richter 2006; Roitman 2014). A closer look into the same analyses and reports unveils a paradoxical reality. In fact, neither assume that tremendous, fundamental change in the art market could or would occur.

I will argue in this article that speculation about the future is at the core of today's art economy. Therefore, in a crisis, market participants conservatively orient themselves toward artworks that already have established value. For this article, I analyzed 86 forecasts originating from both the center and periphery of the global art market. Taking a metaanalytic approach, I concentrated on what each analysis predicts, how it constructs the future it purports to know, and how the expected value of artworks and methods for their purchase are justified. In this context, my title "Why COVID-19 will not change the global art market" is meant to be provocative. This article will not aim toward further speculation about the future but will rather focus on the present. "Time, as often assumed, does not exist" states Elena Esposito (2011, p. 20), who then adds "The past and the future are never given in the concreteness of actuality. What is, is always present". The future is always uncertain, fundamentally unknown, but nonetheless it is by forming expectations, hopes, aspirations, or speculations about the future that economic actors conduct their actions in the present (Beckert 2016; Boltanski 2011b; Esposito 2011). This article's conceptual premise is based on a stream of research in social science which attends to the perceptions of the future as significant, while being often overlooked, explanations of social outcomes (Beckert and Suckert 2021). 
Notions of time and temporality have become pivotal for today's attempts to understand contemporary capitalism (Beckert 2016; Harvey 2005; Rona-Tas and Hiss 2011). A key question asked by economists is: How do we forecast the future to reduce risk and ensure profit? More disinterestedly, a similar question is posed by sociologists: How do people act in conditions of constant uncertainty? Uncertainty inherently accompanies human actions but, as many intellectuals point out, uncertainty has never been higher than it is today, and that is a consequence of how value is currently produced and thus by which profit is gained.

People are trying to deal with an unknown future and thereby reduce uncertainty in various ways. They are trying to gain access to it, but if what exists is present, their reachable future will always be a form of speculation, imagination, or expectation. Such efforts to cope with tomorrow's uncertainty today are conceptualized differently as "fictional expectations" (Beckert 2016; Beckert and Bronk 2018) or "futurework" (Fine 2007; Hoppe 2020). All of these efforts pay attention to how people employ imaginaries, narratives, judgments, and calculations to navigate themselves and make decisions about future actions. Predictions themselves are not incidental. First, they are embedded in social norms, institutions, patterns of action, and culture. Second, their creators are reflexive and observe other observers (Stark 2013; Esposito 2013; Esposito and Stark 2019). All of the above indicates that foreseeing the future is never indifferent because it could be performative. The source of efficiency of every prediction counterintuitively relies on its fallibility. This is a consequence of the fact that prediction usually does not take into account its own appearance. To some extent, this is what Merton (1948) called "the self-fulfilling prophecy".

In this article, I treat analyses considering the future of the art market as fictional expectations, the imaginaries and narratives that people employ to act as if they know the future, providing the confidence needed to undertake actions with unknowable outcomes (Beckert 2016). I treat them as cases of futurework, a concept that emphasizes "the occupational mandate of transforming an uncertain future into determinable information" (Hoppe 2020). Some authors of these analyses, such as Art Basel and UBS, possess an authority that makes their forecasts credible and legitimate, likely more so than some other authors (such as lesser-known journalists or lower-profile journals).

To solve the puzzle posed at the beginning - the paradox of predictions that arises from the conviction in the power of crisis to reformulate the art market, and their conclusions that do not assume the possibility of real change-I will introduce in the next part a pragmatic perspective for artwork value creation, or in Luc Boltanski and Arnaud Esquerre's words, describe "the passage from the state of trash to that of a sought-after object" (Boltanski and Esquerre 2020, p. 183). I will first point out the structures and devices that people employ when trading artworks despite the uncertainty embedded in them. I will then argue that future orientation is fundamental for artwork valuation and, therefore, in a situation of crisis, forecasts play a crucial role in value setting. Later, I will analyze a collection of forecasts of the art market in terms of how market participants cope with uncertainty. I will point out how people assess potential value in artwork and what the fees for these assessments mean. Finally, I will conclude that the paradoxical nature of predictions arises because they are devices involved in artwork value production, and from that comes their conservative bias toward the durability of value and the predictability of the art market.

\section{The Passage from the "State of Trash" to That of a Sought-After Object}

How does an object rise to the status of an artwork? How can it possess value and become a tradable commodity? These questions are central for the sociology of art (Becker 2011; Bourdieu 1996; Moulin 1994; White and White 1993). Artworks are constantly oscillating between two extremes-being a worthless object, trash, or artifact on the one hand and a highly valuable artwork on the other. This uncertainty is inscribed into the existence of all works created by artists. Some of them are forgotten or destroyed as time goes by. Others gain value, or they are rediscovered. The future value of artworks, 
like every future, is uncertain. The value of artworks is exceptionally uncertain since it is based on the valuation of their future. According to Jens Beckert (2020, p. 298), the art market can be understood as a "market from meaning", that is, such markets where "quality is not an inherent feature of the product or cannot be known in the present because of the uncertainty of future development." Moreover, this uncertainty is enhanced by the uniqueness and incommensurability of works created by artists (Karpik 2010).

If the level of uncertainty were too high, there would be no exchange on the art market. It would not be possible to set the price for artworks, and so artworks would not be commodifiable. However, it is evident to all that the art market exists. The last decade has brought visible growth in the volume of transactions and the total value of the global art market (McAndrew 2020a). There must therefore be ways of reducing the uncertainty that enables acting on the market. I perceive the art market as a space that is foremost defined by the circulation of artworks as commodities. After Boltanski and Esquerre (2020), I take a pragmatic perspective on the economy and state that within capitalism there is a plurality of setting value orders. In other words, the value of commodities can be generated in different ways. Inquiring valuation processes can deliver a better understanding of current capitalism conditions.

There are different explanations of how actors deal with uncertainty. One set of conceptualizations in the social sciences focuses on the structural-institutional aspects of reality, while another concentrates on the resources employed by humans. The first group refers to those people's actions that are not accidental but are structured by institutions. According to Boltanski's sociological program, which he has been developing for the last three decades (Boltanski 2011b; Boltanski and Chiapello 2007; Boltanski and Esquerre 2020; Boltanski and Thévenot 2006), institutions are primarily semantic in nature. Their role is to help people determine the "whatness of what is" (Boltanski 2011b, p. 56). Institutions allow people, out of the infinite chaos of reality, to choose which elements they will look at a second time. Boltanski and Esquerre (2020) group institutions that serve to valuate goods under the concept of "forms of valorization". Forms of valorization are discursive structures that enable people to associate things with an appropriate way of valuing them. With these structures, people are able to engage in commodity exchange-to estimate and evaluate prices. In the case of this study, it means that art market participants share a similar conception of artworks as a commodity and valuate them in relation to it.

The second set of conceptualizations focuses on human creative capabilities and human agency. People make use of various devices that help them to reduce uncertainty and to generate and stabilize value. In this context, scholars underscore in contemporary markets the prominent meaning of narratives (Beckert 2016; Beckert and Aspers 2011; Boltanski and Esquerre 2016, 2017, 2020; Boyer 2018). Arranged within narratives are relations among things, persons, actions, and states of the world. Thus a sense-making "plot" is created, one which allows actors to navigate themselves and justify their decisions (Beckert and Bronk 2018). Narratives combine tenses: past, present, and future refer to each other. Narratives are usually not individual, even if a single entity expresses them. This is a consequence of relying on institutions (Boltanski 2011b) and second-order observation (Beckert and Rössel 2013; Esposito and Stark 2019), which allow synchronization or coordination of the actions of heterogeneous actors (Boyer 2018). Researchers also conceptualize other devices, calculative (Callon and Muniesa 2005) and judgmental (Beckert 2020; Karpik 2010.) Both serve to amplify the commensurability of commodities and to deliver and coordinate people's judgments about quality. Calculative devices deliver numbers that allow comparison through calculation - data can be on a micro-scale (e.g., rankings of artists, list of artworks prices) or a macro-scale (e.g., market indices that compare the art markets to other markets) (Lee 2018). There are also algorithms that use such data to calculate the most suitable decisions. Judgment devices take a variety of forms, and Karpik (2010) distinguishes different types, including network, confluence (spatial and time proximity), and authority (e.g., appraisals, rankings, critiques). Serving as examples of these devices are the concepts of futurework and fictional expectations (mentioned in the 
introduction), by which I interpret forecasts of the art market. Art market participants in their activities use different devices, like forecasts, rankings, and prizes, to make decisions to sell or buy a specific artwork more confidently. This consequently stabilizes the value of artworks and thus the trading of art.

The aforementioned structures and devices mark the space in which one should inquire when wishing to examine the valuation process. This article analyzes forecasts of the art market future that consist of specific forms of valorization and devices. I intend to focus only on those that are future-oriented. Regarding different studies, I state that speculation about the future is a fundamental feature of artwork valuation (Boltanski 2011a; Bourdieu 1993; Moulin 2018). I am aware that there are other well-described ways of valuing works of art, but I will not go into them here if they do not exist in connection with the future (Antal et al. 2015; Beckert and Musselin 2013; Hutter and Throsby 2008.)

According to Boltanski and Esquerre (2020), two forms of valorization are characteristic of artworks: they are valued as parts of collections and assets. According to the authors of "Enrichment", the collection form of valorization is dominant for the art market. The collection form includes rare and unique items (Pomian 1990). Their authenticity is essential to their value-closeness to important people, places, and events from the past is appreciated. Goods belonging to this form are taken out of the order of time and are treated as immortal (often they have been created to be so, or they are continuously maintained). Their value depends on their place in the collection or series to which they belong-on how great the lack of a particular totality would be if a specific object were removed. The other form in the art market is the asset form, in which objects like artworks are secondary to money. This is why a significant feature of assets is their liquidity-objects must be easily sellable to be quickly transformable into money. Objects become assets only when they are bought with the intention to maintain or invest capital. They are valuable only if they can bring profit - the value of a specific entity depends mainly on its potential for value growth. This causes a flattening of objects' characteristics because their differences are reduced only to those important for price justification. In this perspective, the various qualities of artwork, such as authorship, content, size, or materials used, are less important to the buyer than its price potential and whether it can be sold.

In the case of artworks as assets, the future orientation is clearly visible. The valuation of an asset is conducted "in terms of the future revenues that it may generate, which presupposes setting the point in time at which these revenues will be received" (Boltanski and Esquerre 2020, p. 247). In the case of artworks as pieces in a collection, the relation with the future not so obvious. The collection form is oriented toward the appreciation of things extracted from the past-establishing a relationship between a commodity and the past allows actors to emphasize its meaning and authenticity. However, within a collection, valued items can be newly created. As the authors of "Enrichment" soberly noticed, "nothing seems more contemporary than contemporary art, not only because it is shaped in the present, but also to the extent that it boasts of being turned toward the future" (Boltanski and Esquerre 2020, p. 213). To sustain their argument, they propose understanding the valuation of contemporary art as a "retroactive movement" situating the valuer "with regard to the work, in the present but from a vantage point to come, as if the work already belonged to the past or, rather, as if it were, in its essence, so to speak, exempt from the corruption of time" (Boltanski and Esquerre 2020, p. 214). At first glance, the distinction is evident-the collection is about the past, the asset is about the future. Paradoxically, as I would like to argue, a closer look reveals that there is more in common between these two forms of valorization. Both are speculations about a future state. A "retroactive movement" is, in fact, another attempt at anticipation. The difference is subtle and concerns the durability of objects-in collection form, objects are treated as if they were immortal; their asset form is more pragmatic and aligns expectations of the object's longevity with the growth potential of its value. This means that the valuation of artworks inside their asset form can take advantage of their durability - there is no contradiction here (Dobeson and Kohl 2020). Additionally, I will argue further that retroactive or speculative 
movements in valuation are not restricted to characteristics of contemporary valuation of artworks, but exist in the case of older, more appreciated artworks.

The above description of valuation refers to valuation in general. In the context of this article, what happens to valuation in times of crisis is important. In the sociology of valuation, more attention has been paid to the underlying reasons for the failure of value-stabilizing devices. It was examined after the fact why, despite active involvement in performing the future, some market participants failed to do so (Boyer 2018; Rona-Tas and Hiss 2011). However, it is important to look precisely at what happens to valuation processes during a crisis. According to Boltanski (2011b) theoretical framework, the current pandemic crisis can be understood as a critical moment, a moment in which increasing levels of uncertainty put existing ways of valuing into question. Such moments can be good subjects for study because they make available to observers the non-obvious rules that determine human actions and how the different value justifications people employ compete with each other. It turns out, nevertheless, as I will argue on the basis of the analysis, that art market participants act in moments of crisis to stabilize and strengthen existing ways of valuing rather than to undermine them.

In the following section, I will use the above framework to analyze forecasts of the art market created in relation to the COVID-19 pandemic crisis. I will examine forecasts as devices and their contents as discursive examples of forms of valorization. On the basis of evident similarities between forecasts, I will argue that all of them perform the same in a generalized art market, which I interpret as a consequence of the growing homogenization of ways of valuing art. I will then summarize forecasters' predictions to present how speculation about the future of artworks lies at the core of their valuations.

\section{The Art Market Future and the Future on the Art Market}

I built this part on a qualitative analysis of 86 forecasts of the art market's future. The main criteria for selecting data for the research were creation time, media coverage, and place of origin. The collected forecasts were published between March 2020 and April 2021. I decided to extend the period of collected materials to the maximum in order to diversify the perspectives as much as possible. As the pandemic continued, market participants began to become used to operating under pandemic conditions, which may have changed the nature of their predictions. In the research sample, 33 forecasts come from the first half of 2020, 39 from the second half of 2020, and 14 from the first half of 2021. Although the data vary by the institution of origin, institution type was not a criterion for selection. The forecasts were created by media and by institutions that specialize in analyzing the art market. I excluded this criterion because the same group of experts-analysts, academics, practitioners-speaks through both. The collected forecasts have miscellaneous formsthere are 10 reports, 44 press articles and analyses, and 31 discussions and interviews with experts. In relation to this, the selection criterion was the size of media coverage. Data were selected for those that had the broadest reach and were created by prominent media and art institutions which are reference points for market participants. The last criterion was the place of origin. The forecasts come both from the world's center and periphery-46 of them were created within the largest art markets, the United States of America and the United Kingdom (in total, 64 percent of the global art market value in 2019), and 40 were created within the comparatively underdeveloped Polish art market (less than 1 percent) (McAndrew 2020a). The collected data were in the English and Polish languages. In the following analysis, I shall denote my statements by the number of forecasts relating to them.

Differentiating the place of origin of forecasts is theoretically important. It is impossible to capture the existence of value, which is immaterial and relational. It is impossible to define precisely where the value exists. It somehow exists simultaneously both in a subject and in an object. It somehow exists simultaneously both locally and globally. Pragmatic sociology, aware of this ambiguity, proposes not to look at the value itself but to look at valuation, that is, how value is produced and how it is used to justify prices. From this 
perspective, reducing valuation to within national borders would be unjustified. Following Prato and Stark (2013, p. 3) work, valuation is located within attention networks-“an evolving network created by multiple agents allocating their attention and expressing their judgments across multiple situations. Valuation [ . . ] is shaped by an actor's location (or viewpoint) within such an attention network". With this in mind, I have chosen central (US, UK) and peripheral (Poland) locations in the global network.

This study proposes qualitative insight into predicting the value of artworks. In this regard, I analyzed narratives that are contained within art market forecasts, and I followed how experts were attempting to predict the future and what kind of justifications of artworks' values they employed in these narratives. Specifically speaking, I extracted from the texts all of the sentences about the future of the art market and interpreted the similarities and differences between them. The frequency of occurrence of specific statements is important but not fundamental to this study - as will be seen further on, some predictions occurred more than 70 times, but others only nine times. I will later argue that there is strong convergence between the forecasts regardless of where they come from-at a general level, they were created based on the same forms of valorization. In this context, the lower frequency of occurrence of some statements is linked to their higher detailedness. This does mean that such statements could appear in other forecasts and so does not make them inconsistent.

\subsection{The Generalized Art Market}

The analyzed material is characterized by significant consistency regardless of the forecasts' place and time of origin. Wherever and whenever forecasts were published, they have much in common. First, they are extremely coherent and undifferentiated in their predictions. As I mentioned before, the basic way actors deal with uncertainty is based on second-order observation. They observe other observers, who in turn build upon their observation of other observers (Esposito 2013; Esposito and Stark 2019). Thus, such analyzed forecasts quote and refer to each other constantly. Among them, there are noticeable opinion makers who are used frequently as the most credible source of expertise-Art Basel and UBS, Artprice reports in general, and ArtInfo in Poland. The second common feature of forecasts is the object of their predictions. They generally write about the various national, regional, and global markets, but they do so to indicate the level of aggregation of the data. Nonetheless, most of them refer to the generalized art market, which has no geographical or national contours (79 forecasts in total: in English 42, in Polish 37). The nature of the generalized art market is, in fact, an abstract construct, which describes the rules of the art market as if they were universally genuine for any art market wherever it is located. This acts as a reference point or imagination of how the art market works, or what should be valuable and why. In consequence, such a concept does not make geographical divisions. The similarity of peripheral and central descriptions of the generalized art market reveals that the dominant forms of valorization, the status of the artworks as commodities and, tangled in them, ways of valuations, have more in common than it may appear. Therefore, I argue that strong similarities between forecasts show that they perform in the same art market.

What lies behind this generalized art market? I understand it foremost as a stream of narratives that, as I mentioned earlier, arrange the relationships between things, persons, actions, and states of the world. They coordinate the strategies of heterogeneous actors because people use them to navigate themselves and justify their decisions (Boyer 2018; Collier and Tuckett 2021). Thereby, these narratives have crucial meaning in commodifying things by specifying how they should be valued. The most important observation is that there is no remarkable division into forms of valorization in the forecasts. What is, however, visible is a form that combines elements of both collection and asset forms (55 forecasts in total: in English 34, in Polish 21). Artworks are presented as commodities bought for collection or investment objectives; thus, buying art is some combination of collecting and investing. As I would like to argue, the distinction between these purposes is not 
fundamental for the commodification process and holds mostly symbolic meaning (Velthuis 2007). There are different usages of the notion of "investment", and it is important that they are usually relational. First, it exists neutrally as a synonym of purchase, positively as the opposite of speculation, and negatively as the opposite of collection. These distinctions do not fundamentally refer to the commodity but to the power position of its owners. This is clearly visible in the case of "collector-advisor-dealer" Stefan Simchowitz, whose activity is described in one of the reports as "speculative" because of his engagement in enhancing specific artwork prices, while a few sentences later, the well-known gallerist Emmanuel Perrotin is designated as someone "who seems gifted at anticipating cultural phenomena" (Ehrmann 2020, p. 46). It is thus impossible to convincingly draw a clear demarcation line between speculation and investment. As Esposito (2011, p. 77) points out, "In all cases where an operator hopes to gain, by buying now with the intention of selling later at a higher price, he/she is placing a bet on the expectations of him/herself and others". Such boundary work (Bodnar and Molnar 2010; Lamont 2000) is an outcome of domination struggles, which is important but is not a subject of this study, and I will primarily focus on the anticipatory aspect of their activity.

\subsection{The Future That Is to Come}

"Art has always been a safe house in uncertain times" assures Nicholas Maclean (Brady 2020). I will concisely summarize the fictional expectations provided in the analyzed material. In most forecasts, there exists a firm conviction about the uniqueness of the art market, which distinguishes it from others (53 forecasts in total: in English 26, in Polish 27). The art market is governed by different rules that increase its resistance to external factors. According to the forecasts, the art market will grow as it generally has over the last few decades. The prices of artworks will probably not fall—they will instead stably retain their value. Market growth can be perceived by a volume of transactions or transactional prices, but also by the number of market participants, primarily collectors, and their willingness to purchase art. According to the Art Basel and UBS report, "Across all of the HNW collectors surveyed, 59\% felt the COVID-19 pandemic had increased their interest in collecting, including 31\% saying that it had significantly done so" (McAndrew 2020b, p. 11). This trend is expected to continue, and the number of collectors will gradually increase (43 forecasts in total: in English 22, in Polish 21). The rich are spending more time locked down in their residencies and they are bored with their interior design; also, they are spending less money on some other status luxury services. That is why the rich will probably be more willing to impulsively spend their growing savings on artworks. In addition, wherever the prediction comes from, there is a sense of confidence that a new generation of collectors is coming into play (13 forecasts in total: in English 7, in Polish 6). Wealthy millennials are treated as the future of the art market-they consume much more than their parents, and they have less sentiment and are therefore more likely to use the internet to buy art.

Even if the art market's future seems to be bright, some turbulence may occur. It will take place mainly in the gallery sector, which may experience a decline in current revenues, and in the employment sector, where numerous public and private art institutions have already downsized staff or announced their intentions to do so (19 forecasts in total: in English 12, in Polish 7). The forecast authors share a firm conviction that art market intermediaries will come out on top after the pandemic (32 forecasts in total: in English 19, in Polish 13). The source of their confidence is their belief in the ability of art market participants to adjust themselves to changing conditions. There is an established link between the characteristic tendency of artists towards novelty and innovation and art institutions, which should, in their opinion, share the same tendencies (that, obviously, is a misconception). In the above context, an imperative for adjustment is evident ( 31 forecasts in total: in English 18, in Polish 13). Participants should adjust themselves to the current situation. To support such a claim, one of the experts even used a Darwinian metaphor, saying that those who win the competition "will not be the strongest, but those with the 
highest capacity to adapt" (Easiczka 2020). There is also hope expressed that the pandemic will be a catalyst for change (28 forecasts in total: in English 16, in Polish 12).

Let us look closer at these expected market transformations. The prevailing opinion in the analyzed corpus is that in upcoming years there will be an observable shift of the art market toward digitalization (55 forecasts in total: in English 34, in Polish 21). More and more participants will be presenting and selling artworks online. More events will take place virtually. There will be a noticeable expansion of various hybrid business models-much has been written about bricks-and-clicks models which integrate physical and digital presentation. Accessibility to wider audiences will also increase-it will be easier for them to view and purchase artwork. One of the most visible imperatives for change is the enhancement of price transparency (21 forecasts in total: in English 12, Polish 9). The forecast authors encourage gallerists to make traded artwork prices public-this is expected primarily in the case of the online model. Other shifts will take place on both the geographical and operational scales. The first concerns the oft-repeated phrase "local is the new global", meaning that galleries should take advantage of the communities in which they are located (18 forecasts in total: in English 14, in Polish 4). Second, the market will consolidate, which means that the position of the stronger participants will be strengthened, and their standards will be imposed (9 forecasts in total: in English 7, in Polish 2). Based on predictions from the forecasts, I shall draw further analysis and emphasize how these possible futures refer to artwork valuations.

\subsection{Valuing the Future}

Time and speculation about the future are central to the activity of market participants. In the analyzed material, much is written about the potential of an artwork and how to assess it. An artwork's potential, like every potential, exists in the present but strictly refers to the future. As Kosmala (2020) writes, "It is only possible to play for an upward trend in the short term if the object really has potential". It should be understood that in the present, there exist artworks that are immersed at the same time in the future or, to be more specific, in our imaginations of the future. This potential could be defined as confidence about the high probability of the object's future state. A collector looking for an artwork to purchase will valuate it in terms of whether it is valuable because it may be valuable in the future. There is no difference between what the valuer has in mind-disinterested artwork importance or self-interested artwork preciousness - both valuations support each other. Such a collector could choose those from the universe of artworks for which the future is quite certain, or from that which is uncertain. As the authors of "The Global Art Market and COVID-19 Innovating and Adapting" report remark, "Amid an economic downturn, as in 2009, high-quality works of art have provided tangible safe havens for collectors" (Gyorgy et al. 2020, p. 48). Such a distinction between works bearing lower and higher risk is considerably visible in a large number of forecasts (38 forecasts in total: in English 19, in Polish 19). To the first stream belong highly recognized works, like those of the Old Masters segment or the most valuable works of the modern or contemporary art segment. To the second stream belong the rest of the artworks, those of more ambiguous status, especially contemporary artworks created by newcomers to the art world-in Poland known as the Young Art segment. This brings us to the language of the financial markets, where there are safe treasury bonds or deposits that serve well for placement purposes (to retain value or increase it slightly), and the alternative risky derivatives that serve investment purposes (to obtain the highest possible return). This analogy is present in the analyzed data, like in the following example: "Art is like the stock market, you can buy shares of start-ups and expect to make a lot of money, because 1 in 100 will work out, and you can invest in shares of companies recognized on the market, the so-called black horses" (Forbes Editorial 2021). This logic is the same whether considering the asset or collection forms of valorization, because in both cases the advantage is taken from the uncertainty of the future. In the asset form, an investor takes a higher risk to generate a higher profit. Equivalently, in the collection form, a person who is running a new collection-for instance, first deciding 
to buy works of an unknown artist-has an advantage over other collectors who would start collecting once these artworks have already appreciated (Boltanski and Esquerre 2020, pp. 186-88). This synonymity is well grasped in the words of a collector commenting on the behavior of other market participants: "They do not spoil the fun for me at all. On the contrary, they buy Fangor's [the famous Polish painter-F.T.] paintings for a million zlotys, which I bought many years ago for 10,000. I look for artists at auctions who they will be looking for only in 10-15 years. Then they will be classics. This is what it's all about" (Bartman 2020).

This all brings us to the issue of novelty and innovation in the art market. The most uncertain objects are those that are newly created and those that are forgotten. These are works whose status is vague and for which their value has not yet been fully established. A valuer perceives such objects in terms of their potential. From the valuer's perspective, the objects are undervalued and they put them through tests that could uncover the "real value" of the specific object. One of the most fundamental tests on the art market is transactions. This is mostly, as I argue, because of the price, which is the transaction outcome, expressing value in an empirical form. Price becomes one of the most profound factors of artwork value. The development of analytical tools has made many qualities of artworks more accessible and measurable, as is explained in the following quote: "The increasing access to data and analytics may provide sophisticated buyers with more transparency and detail on potential purchases, which in turn may impact the prices that artworks will achieve at auction" (Barclay and Pizzo 2020).

This brings us to the asset form of valorization, where the potential price is the main valuation principle. In this context, one understands price as a crucial quality signal (Beckert and Rössel 2013) which provides important justifications for the valuation of a specific artwork. This is evident in the frequently repeated market rules such as "what was once expensive is now even more expensive" (Wojciechowski 2020) or "higher-priced works tended to perform better than lower-priced works" (Gyorgy et al. 2020, p. 9). In this context, it should come as no surprise that it has become a reality that the art market is defined by prices, especially by the highest ones. To use the words of cultural critic Fran Lebowitz: "That's what we hear about. The prices. I mean, if you go to an auction, out comes the Picasso, dead silence. Once the hammer comes down on the price, applause. We live in a world where they applaud the price but not the Picasso. They applaud the price!" (Scorsese 2021). Such appreciation of high prices can be interpreted in terms of moral outrage, but there is another explanation. It could be treated as a strengthening of the analogy between artistic and monetary values (Moulin 2018; Zarobell 2020), and, with regard to this appreciation of price, should be interpreted as appreciation of passing a significant test-the market test.

It is not the case that all prices are equally reliable. First, the most credible are those that are outcomes of transactions. Second, market participants assess the context in which prices appear, which could give additional confidence about the credibility of a price. On the art market, auction houses and galleries are the important pricing places. The former are especially crucial because of their public character (which of course does not restrict confidentiality) and appreciation of the prices. Such institutions are at the center of attention networks and they influence how participants valuate artworks. The onset of the COVID-19 pandemic led to public art events being canceled and galleries and museums being locked down. The authors of forecasts have expressed concerns about the suspension of the art market, especially the part responsible for sending quality signals (18 forecasts in total: in English 11, in Polish 7). One collector said: "There is nothing publicly to test the market-no fairs or auctions. It's holding up business. People don't really know at what price to trade" (Pogrebin et al. 2020). Prices are essential for economic actors to navigate themselves - if the number of published prices drops dramatically, they have to justify their acquisition decisions because uncertainty about the value of the works increases markedly at the same time. Out of this comes their distrust of digital trade. Until now, prices for works sold exclusively online have been comparably lower than in traditional 
sales. Therefore, in the analyzed forecasts, there is visible pressure on sellers to convince their clients that this kind of trade is as legitimate as conventional trade ( 22 forecasts in total: in English 13, in Polish 11). One expert provides reassurance that, "Once you get to a point where people see online sales maximizing or exceeding value, that would be the tipping point; that's when you'll see our business going broadly online" (Pogrebin et al. 2020).

A response to the distrust could be bricks-and-clicks models that do not forsake physical locations but at the same time appreciate digital trade. Artworks should be presented on the internet with a similar degree of precision with which they are presented on site. This means an accurate description of artworks, their physical characteristics, their provenance, their creators' profiles, and everything else pertinent to their prices. Expanding price transparency is one of the most expected trends in the art market. As Barclay and Del Barclay and Pizzo (2020) argue, "The art market may be ushering in a new world of data, transparency, and efficiency, which could make it even more appealing than it was before". Lack of prices is understood as one of the main barriers to entry into the art market. The argument is that price publication allows entrants to overcome the inaccessibility of the elite art world and encourage potential newcomers, again by demonstrating that many artworks are accessible. Transparent prices could help participants gain higher confidence about their actions and valuate and compare artworks more analytically. The visible price transparency imperative comes with another prominent consequence: it strengthens liquidity in the art market. Boltanski and Esquerre (2020) point out five factors that reveal liquidity: transportability, confidentiality, the existence of institutions that can determine the characteristics of things and give price references, the ease of finding a buyer and quick sale, and the number of collectors. It thus becomes clear that the reinforcement of price transparency refers directly to at least three of these factors. The increasing liquidity of artworks brings them closer to being an asset. This phenomenon is evident when we take a look at the current market boom in non-fungible token (NFT) artworks. Cryptoart marketplaces, such as Foundation.app, Niftygateway, and Opensea, are extreme forms of assetization that makes trading art similar to trading on the stock market (Birch and Muniesa 2020; Sidorova 2019). Everyone has access to it, artworks are traded in real time, and all records are transparent. I do not want to say that this is how the art market will look in the future, but rather that changes in the art market infrastructure can enhance a specific form of valorization.

In this analysis, I have presented how market participants are valuing the future as they try to deal with the uncertainty that prevails on the art market. Artworks are compared in terms of their potential. I pointed out that among the many ways to assess potential, valuation through price-related devices is particularly important. In moments of crisis, market participants are directed toward works that already have value-the current price is a crucial argument for the future price. This reinforces conservative attitudes towards action. This observation resonates with the art market transformations described by Raymonde Moulin (2018), who stated that we are witnessing the disappearance of the avant-garde and the emergence of a primacy of novelty. That is to say, the contemporary art world is reevaluating only the artworks themselves, and not the institutions that exhibit and market them. In the context of my study, this would be associated with the development of the art market and a greater emphasis on stability and, thus, to some extent, predictability.

\section{Conclusions}

The puzzle stated at the beginning pointed out the paradox of predictions which shared a conviction about the power of crisis to reformulate the art market, but their outcomes did not assume the possibility of real change. These forecasts were concerned about the future of the art market, but at the same time, they were confident that the art market would deal with current turbulences. After analyzing the forecasts, I can offer at least two convincing answers to this puzzle. The first is that the forecasts do not only describe possible scenarios of the future, but they are actively committed to creating the future. They are employed to reduce uncertainty and, thus, to help accurately valuate 
artworks. The analyzed data are not only a set of narratives or imaginations, but they also have a strong normative character. As I mentioned earlier, there is clearly an imperative of adaptation, according to which market participants should adapt efficiently and quickly to changing conditions. The normative character was also noticeable in the explicit expectation of digitalization and price transparency.

The second answer is that art market participants are orientated toward stability and internal consistency. It comes to form their efforts to reduce the uncertainty surrounding the value of artworks. This uncertainty is mitigated not only by employing the aforementioned devices but, importantly, it is reduced on a much more fundamental level by likening the ways artworks are valued and how their value is justified. According to Boltanski and Esquerre (2017), profiting from such a heterogenous world as art is possible through the integration of the market into one forcefield, within which financial flows create interdependencies and even solidarity among participants. Of course, it does not exclude the possibility of intense competition among them, but it does protect against fundamental changes in forms of valorization. Otherwise, the existing order of value could be reshaped or shattered, which could reduce the certainty of profiting. The reaction of market participants to the growing uncertainty surrounding the pandemic is a movement towards strengthening the dominant forms of valuation. This is why analysts are calling for greater price transparency and digitalization of the market. Additionally, this is why analysts are encouraging a conservative attitude toward action in the market-saying that what has a value has a price. They prompt buyers to buy established and more expensive works, claiming that this is the best investment in uncertain times. Regardless of whether forecasts come from the center or the periphery, they show the existence of the stream of narratives which I called the generalized art market. At the center of this concept is that it describes the art market as if it were universal, with the same principles of valuation-like valuation in terms of potential future increases in value. In the analyzed data, there are no profound differences between the two dominant forms of artwork valorization-asset and collection. They reinforce each other rather than contradict each other. With reference to Nancy Fraser (2017), I would like to argue that the asset form is dominant for our current highly financialized economy. Therefore, different forms of valorization are adjusted to it, and more and more commodities come under this form. This is how I understand the changes that are amplifying the liquidity of artworks.

Following the above conclusions, I state that even in such uncertain times of crisis, such as the current pandemic, some elements remain durable and are more resistant to change. On the fundamental level, there are forms of valorization, the semantic structures responsible for establishing the order of commodities. There are different lower levels of change usually entangled with the dominant form of valorization, like market infrastructure and devices, but they are historically more volatile and fragile under changing external conditions.

Funding: This research was funded by the Polish National Science Centre, grant number 2019/35/N/ HS6/01634.

Institutional Review Board Statement: Not applicable.

Informed Consent Statement: Not applicable.

Acknowledgments: I would like to sincerely thank those who are close to me and my colleagues for their tremendous support, kind words, and accurate comments, especially Zofia Rohozinska, Mikołaj Lewicki, Mateusz Halawa, Marcin Serafin, and Andrew Tuson. Additionally, I would like to thank the two anonymous reviewers who provided invaluable feedback.

Conflicts of Interest: The author declares no conflict of interest.

\section{References}

Antal, Ariane Berthoin, Michael Hutter, and David Stark, eds. 2015. Moments of Valuation: Exploring Sites of Dissonance. Oxford: Oxford University Press. 
Barclay, Rachel, and Arianna Del Pizzo. 2020. The Impact of a Global Pandemic on the Art Market. AON. 2020. Available online: https: / / www.aon.com/unitedkingdom/insights/impact-of-a-global-pandemic-on-the-art-market.jsp (accessed on 15 May 2019).

Bartman, Katarzyna. 2020. Koronawirus Zmienił Podejście Do Inwestycji. Dzieła Polskich Artystów Biją Rekordy. Money.pl. December 4. Available online: https:/ / www.money.pl/gospodarka/koronawirus-zmienil-podejscie-do-inwestycji-dziela-polskich-artystowbija-rekordy-6497015176366209a.html (accessed on 15 May 2019).

Becker, Howard Saul. 2011. Art Worlds. Berkeley: University of California Press.

Beckert, Jens. 2016. Imagined Futures. Cambridge: Harvard University Press.

Beckert, Jens. 2020. Markets from Meaning: Quality Uncertainty and the Intersubjective Construction of Value. Cambridge Journal of Economics 44: 285-301. [CrossRef]

Beckert, Jens, and Patrik Aspers. 2011. Value in Markets. In The Worth of Goods: Valuation and Pricing in the Economy. Edited by Jens Beckert and Patrik Aspers. New York: Oxford University Press.

Beckert, Jens, and Richard Bronk, eds. 2018. Uncertain Futures: Imaginaries, Narratives, and Calculation in the Economy. Oxford: Oxford University Press.

Beckert, Jens, and Christine Musselin, eds. 2013. Constructing Quality: The Classification of Goods in Markets. Oxford: Oxford University Press.

Beckert, Jens, and Jörg Rössel. 2013. The Price of Art: Uncertainty and Reputation in the Art Field. European Societies 15: 178-95. [CrossRef]

Beckert, Jens, and Lisa Suckert. 2021. The Future as a Social Fact. The Analysis of Perceptions of the Future in Sociology. Poetics 84: 101499. [CrossRef]

Assetization: Turning Things into Assets in Technoscientific Capitalism. 2020. Birch, Kean, and Fabian Muniesa, eds. Inside Technology. Cambridge: The MIT Press.

Bodnar, Judit, and Virag Molnar. 2010. Reconfiguring Private and Public: State, Capital and New Housing Developments in Berlin and Budapest. Urban Studies 47: 789-812. [CrossRef]

Boltanski, Luc. 2011a. Od Rzeczy Do Dzieła. Procesy Atrybucji i Nadawania Wartości Przedmiotom. In Wieczna Radość.Ekonomia Polityczna Społecznej Kreatywności. Edited by Jan Sowa. Warszawa: Fundacja Nowej Kultury Bęc Zmiana, pp. 17-47.

Boltanski, Luc. 2011b. On Critique: A Sociology of Emancipation, English ed. Cambridge: Polity, Malden: Polity.

Boltanski, Luc, and Ève Chiapello. 2007. The New Spirit of Capitalism. London: Verso.

Boltanski, Luc, and Arnaud Esquerre. 2016. The Economic Life of Things. New Left Review 98: 31-54.

Boltanski, Luc, and Arnaud Esquerre. 2017. Enrichment, Profit, Critique. New Left Review 106: 67-76.

Boltanski, Luc, and Arnaud Esquerre. 2020. Enrichment: A Critique of Commodities. Cambridge and Medford: Polity Press.

Boltanski, Luc, and Laurent Thévenot. 2006. On Justification: Economies of Worth. Princeton: Princeton University Press.

Bourdieu, Pierre. 1993. The Field of Cultural Production: Essays on Art and Literature. Edited by Randal Johnson. New York: Columbia University Press.

Bourdieu, Pierre. 1996. The Rules of Art: Genesis and Structure of the Literary Field. Stanford: Stanford University Press.

Boyer, Robert. 2018. Expectations, Narratives, and Socio-Economic Regimes. In Uncertain Futures: Imaginaries, Narratives, and Calculation in the Economy. Edited by Jens Beckert and Richard Bronk. Oxford: Oxford University Press, pp. 39-61.

Brady, Anna. 2020. "One of the Most Shocking, Tumultuous Years on Record": Art Market Figures Reflect on 2020-And Guess at What 2021 Might Hold. The Art Newspaper. November 25. Available online: https://www.theartnewspaper.com/analysis/whatthey-said-the-art-market-in-2020-and-2021 (accessed on 15 May 2019).

Callon, Michel, and Fabian Muniesa. 2005. Peripheral Vision: Economic Markets as Calculative Collective Devices. Organization Studies 26: 1229-50. [CrossRef]

Collier, Paul, and David Tuckett. 2021. Narratives as a Coordinating Device for Reversing Regional Disequilibrium. Oxford Review of Economic Policy 37: 97-112. [CrossRef]

Dobeson, Alexander, and Sebastian Kohl. 2020. Why Durability Matters? Towards a Comparative Economic Sociology of Market Organization. European Journal of Sociology/Archives Européennes de Sociologie 61: 33-64. [CrossRef]

Ehrmann, Thierry. 2020. Artprice Report 2000-2020. Lyon: Artprice.

Esposito, Elena. 2011. The Future of Futures: The Time of Money in Financing and Society. Cheltenham and Northampton: Edward Elgar. Esposito, Elena. 2013. Economic Circularities and Second-Order Observation: The Reality of Ratings. Sociologica 2: 1-10. [CrossRef]

Esposito, Elena, and David Stark. 2019. 'What's Observed in a Rating? Rankings as Orientation in the Face of Uncertainty'. Theory, Culture \& Society 36: 3-26. [CrossRef]

Fine, Gary Alan. 2007. Authors of the Storm: Meteorologists and the Culture of Prediction. Chicago: University of Chicago Press.

Forbes Editorial. 2021. Sztuka Zarabiania Na Sztuce. Available online: https:/ / www.forbes.pl/inwestowanie/rynek-dziel-sztuki-wpolsce-w-2020-i-2021-roku-eksperci-kresla-scenariusze/0w81r4r (accessed on 15 May 2019).

Fraser, Nancy. 2017. A New Form of Capitalism? New Left Review 106: 57-65.

Gyorgy, Suzanne R., Dominic Picarda, Fotini Xydas, and Steven C. Wieting. 2020. The Global Art Market and COVID-19. Innovating and Adapting. New York: Citigroup.

Harvey, David. 2005. A Brief History of Neoliberalism. Oxford and New York: Oxford University Press.

Hoppe, Alexander D. 2020. Coordinating Transnational Futurework in Fashion Design. Socio-Economic Review, mwaa046. [CrossRef] 
Hutter, Michael, and C. D. Throsby. 2008. Beyond Price: Value in Culture, Economics, and the Arts. Cambridge: Cambridge University Press, New York: Cambridge University Press. [CrossRef]

Karpik, Lucien. 2010. The Economics of Singularities. Princeton: Princeton University Press.

Koselleck, Reinhart, and Michaela Richter. 2006. Crisis. Journal of the History of Ideas 67: 357-400. [CrossRef]

Kosmala, Weronika A. 2020. 10 Kryzysowych Pytań o Rynek Sztuki. Forbes. May 27. Available online: https://www.forbes.pl/opinie/ epidemia-koronawirusa-i-kondycja-rynku-sztuki/z9p85q5 (accessed on 15 May 2019).

Lamont, Michèle. 2000. The Dignity of Working Men: Morality and the Boundaries of Race, Class, and Immigration. New York: Russell Sage Foundation.

Łasiczka, Cezary. 2020. 'Świat Sztuki Po Covid-19'. OFF Czarek. Tok FM. Available online: https://audycje.tokfm.pl/podcast/90372, Swiat-sztuki-po-covid-19 (accessed on 15 May 2019).

Lee, Kangsan. 2018. Neoliberal Marketization of Global Contemporary Visual Art Worlds: Changes in Valuations and the Scope of Local and Global Markets. In Art and the Challenge of Markets Volume 2: From Commodification of Art to Artistic Critiques of Capitalism. Edited by Victoria Alexander, Samuli Hägg, Simo Häyrynen and Erkki Sevänen. London: Palgrave Macmillan.

McAndrew, Clare. 2020a. The Art Market 2020. Basel: Art Basel and UBS, Zurich: Art Basel and UBS.

McAndrew, Clare. 2020b. The Impact of COVID-19 on the Gallery Sector. Basel: Art Basel and UBS, Zurich: Art Basel and UBS.

Merton, Robert. 1948. The Self-Fulfilling Prophecy. The Antioch Review 8: 193-210. [CrossRef]

Moulin, Raymonde. 1994. The Construction of Art Values. International Sociology 9: 5-12. [CrossRef]

Moulin, Raymonde. 2018. The Museum and the Marketplace: The Constitution of Value in Contemporary Art. In Bourdieu in Question: New Directions in French Sociology of Art. Edited by Jeffrey A. Halley and Daglind E. Sonolet. Leiden: Brill, Boston: Brill, vol. 130, pp. 43-70.

Pogrebin, Robin, Scott Reyburn, and Zachary Small. 2020. Auction Houses Postpone Live Sales and Pivot to Online. The New York Times. April 19. Available online: https:/ / www.nytimes.com/2020/04/19/arts/design/art-auction-houses-sales-coronavirus.html (accessed on 15 May 2019).

Pomian, Krzysztof. 1990. Collectors and Curiosities: Paris and Venice 1500-1800. Cambridge and Cambridge: Polity Press.

Prato, Matteo, and David Stark. 2013. Attention Networks: A Two-Mode Network View on Valuation. Academy of Management Annual Meeting Proceedings, 1. [CrossRef]

Roitman, Janet L. 2014. Anti-Crisis. Durham: Duke University Press.

Rona-Tas, Akos, and Stefanie Hiss. 2011. Forecasting as Valuation: The Role of Ratings and Predictions in the Subprime Mortgage Crisis in the United States Akos Rona-Tas and Stefanie Hiss. In The Worth of Goods: Valuation and Pricing in the Economy. Edited by Jens Beckert and Patrik Aspers. New York: Oxford University Press.

Scorsese, Martin. 2021. Pretend It's a City. Episode 2. TV Mini Series. Los Gatos: Netflix.

Sidorova, Elena. 2019. The Cyber Turn of the Contemporary Art Market. Arts 8: 84. [CrossRef]

Stark, David. 2013. Observing Finance as a Network of Observations. Sociologica 2: 21-25. [CrossRef]

Velthuis, Olav. 2007. Talking Prices: Symbolic Meanings of Prices on the Market for Contemporary Art. Princeton: Princeton University Press.

White, Harrison C., and Cynthia A. White. 1993. Canvases and Careers: Institutional Change in the French Painting World. Chicago: University of Chicago Press.

Wojciechowski, Konrad. 2020. Nie Lada Sztuka, Czyli Rynek Aukcji Świetnie Radzi Sobie w Pandemii. Gazeta Wyborcza. December 29. Available online: https:/ / wyborcza.pl/7,155068,26621350,nie-lada-sztuka-czyli-rynek-aukcji-swietnie-radzi-sobie-w-pandemii. html (accessed on 15 May 2019).

Zarobell, John. 2020. Freeports and the Hidden Value of Art. Arts 9: 117. [CrossRef] 